\title{
Adaptation Options for Land Drainage Systems Towards Sustainable Agriculture and the Environment: A Czech Perspective
}

\author{
Zbyněk Kulhavý, Petr Fučík* \\ Department of Hydrology and Water Protection, Research Institute for Soil and Water Conservation, \\ Žabovřeská 250, Praha 156 27, Czech Republic
}

Received: 14 October 2014

Accepted: 6 February 2015

\begin{abstract}
This paper introduces issues of agricultural drainage systems from the views of former, current, and future roles and the functioning of these systems in Central Europe. A methodologically disparate survey was done on 39 model locations in the Czech Republic with different intensities and states of land drainage systems, aimed at describing commonly occurring problems and possible adaptations of agricultural drainage as perceived by farmers, land owners, and landscape managers, or by protective water management. The survey was focused on the technical state of the systems, fragmentation of land ownership within drained areas, and on possible conflicts between agricultural and environmental interests in a landscape. Achieved results confirmed that there is obviously an increasing need to reassess some functions of prevailingly single-purpose agricultural drainage systems. Drainage intensity and the detected unfavourable technical state of drainage systems as well as the risks connected with the anticipated climate change from the view of possible water scarcity claims for a complex solution. An array of adaptation options for agricultural drainage systems is presented, aimed at enhancement of water retention time and improvement of water quality. It encompasses additional flow-controlling measures on tiles or ditches, or facilities for making selected parts of a drainage system inoperable in order to retain or slow down drainage runoff. However, it was revealed that the question of landowner parcels fragmentation on drained land would dramatically complicate the design and realization of these measures. Presented solutions and findings are propounded with respect to contemporary and future state policies and international strategies for sustainable agriculture, water management, and the environment.
\end{abstract}

Keywords: drainage systems adaptation, water management, land owners, controlled drainage

\section{Introduction}

Agricultural drainage systems have traditionally served the optimization of soil water balance for crop production and soil management. In the Czech Republic (CR), installation of drainage systems started in the second half of the

*e-mail: fucik.petr@vumop.cz $19^{\text {th }}$ century [1]. At that time, an exact engineering approach was applied, which proposed principles for drain spacing and depths in mineral agricultural soils based on foreign and domestic experience. However, the majority of Czech agricultural drainage systems was built in the $20^{\text {th }}$ century, during three discrete periods. The first period came shortly before World War I, the second boom took place between the World Wars, and the third wave - and by far the largest 
- took place similarly as in other countries of the former Eastern Europe bloc, between 1960-80.

Massive drainage construction, situated in the CR even in marginal or submontane zones, was carried out mainly in conditions of collective/cooperative agricultural land management [2-5]. Construction of land drainage was supported by the state and, during the first two periods, also by voluntary activities of farmers' associations, called water cooperatives. The water cooperatives started to constitute in the Czech territory around 1880-90 and were composed of civil engineers, farmers, and landowners. These associations helped with agricultural water management, proposals, and construction of land drainage, for which they acquired consensus across the involved legal persons as well as farmers/land owners. In 1955 the water cooperatives were cancelled.

Works connected with the design and construction of land drainage, its management, and maintenance were further passed on to the Agricultural Water Management Authority (AWMA), a state organization that also supervised, e.g., some related soil conservation practices. A detailed scheme (Table 1) shows the time course and interconnections of land drainage administration and management, as concerned with the legal-, property- and management-related issues between in 1948-2013.

Changes in the political situation in CR after 1989 brought significant consequences to the ownership of both land parcels and drainage systems [6]. Until this time, a priority was given to the interests of the managing agricultural entity over those of the land parcel owner. This simplified the design and construction of agricultural drainage systems. After 1991, however, with the rehabilitation of property rights, the maintenance and repairs of the established drainage systems became problematic. The CR agricultural sector at that time had to meet more essential demands, especially when the drainage system more or less functioned.

Agricultural drainage systems in CR were built overall on $1,078,000$ ha, which is about $25 \%$ of agricultural land. The systems were constructed prevailingly (98\%) as subsurface tile drainage (made from fired clay and after about 1978, also from plastic), called drainage system detail (DSD). DSD were flow-connected either to adjusted (straightened, deepened) small water courses, or to drainage ditches. The ditches, of the total $12,185 \mathrm{~km}$ length, were built either open $(6,835 \mathrm{~km} ; 60 \%)$ or tubed $(5,350 \mathrm{~km} ; 40 \%)$. Drainage ditches together with small water courses are labelled as the main drainage systems (MDS) [7].

In the past 25 years, the branch of soil conservation and landscape water management has mostly met criticism from environmentalists in CR, pointing out the high proportion of landscape artificial draining and often its technical character. During this period (1990-2005), the occurrence of drainage failures (drainage clogging, collapses of pipes, damage of drainage shafts and outlets, etc.) was rather low and did not essentially hamper agricultural activities (i.e. farmers were able to do the repairs on agricultural drainage by themselves, without extensive costs).
Even though the government provided funding for repairs of the drainage systems, the support was not extensively employed (due to a low awareness of farmers and land owners) and after some years it was consequently abolished (2006). CR political representation did not even consider the expert proposals for re-establishment of water cooperatives, despite their obvious importance for agricultural water management and farmer cooperation, as experienced in CR in the past as well as abroad [12-14]. The arguments against water cooperatives have not significantly changed in time, as about $82 \%$ of agricultural land in CR is leased, and the owner of the land parcel (and so of the drainage system) may not be aware of the existence and condition of land drainage. However, the Czech Water Law declares it the owner's duty to duly maintain the land parcel, including any placed structure or object. Effective operation of the entire drainage system thus requires cooperation of all owners of the drainage structures or their parts.

The long period during which the authorities or the managing farmers have not given systematic care to the drainage systems in the CR is now being manifested in several simultaneous manners. The neglect of maintenance and the growing age of artificial drainage systems has caused undesirable wetting of the land parcels or even surface runoff caused by outflow of drainage water. The initiative is then taken by farmers, who perform the maintenance and partial repairs, but only up to an acceptable limit, beyond which they should withdraw from the lease as a user. Higher investments on drainage are dampened by the risk of a lease agreement cancellation by the owner, especially at places close to the urban areas (speculative sales of land parcels, for example). However, the stabilizing function of land drainage for crop production and soil management is perceived by farmers positively.

Professional expertise for land drainage is currently practically non-existent in $\mathrm{CR}$, and generational exchange of related specialists did not happen to a sufficient extent. Targeted funding is actually missing, and the state archives of drainage project documentations suffer severe gaps because the original state investor institution for land drainage (AWMA) administering the archives underwent several rounds of transformation, and in the end it was abolished (on 30 June 2012). AWMA created and maintained a Territorial Information System of Irrigation and Drainage Structures (T-IS), which consisted of a database and paper materials (maps, project proposals of drainage systems, etc.) both for DSD as well as for MDS. Later, information and a rough placement of DSD and MDS were converted to a digital GIS layer. The T-IS thus enabled them to follow the functional (i.e. hydrological, hydrochemical) integrity between DSD and MDS.

By dividing the competencies in administering the T-IS, awareness of the interconnection between DSD and MDS has been lost, resulting in numerous operational and environmental problems, especially during drainage system maintenance or repairs. Besides this, the actually valid law in $\mathrm{CR}$ does not adequately enforce cooperation between individual land owners or users with the representatives of state administration. 


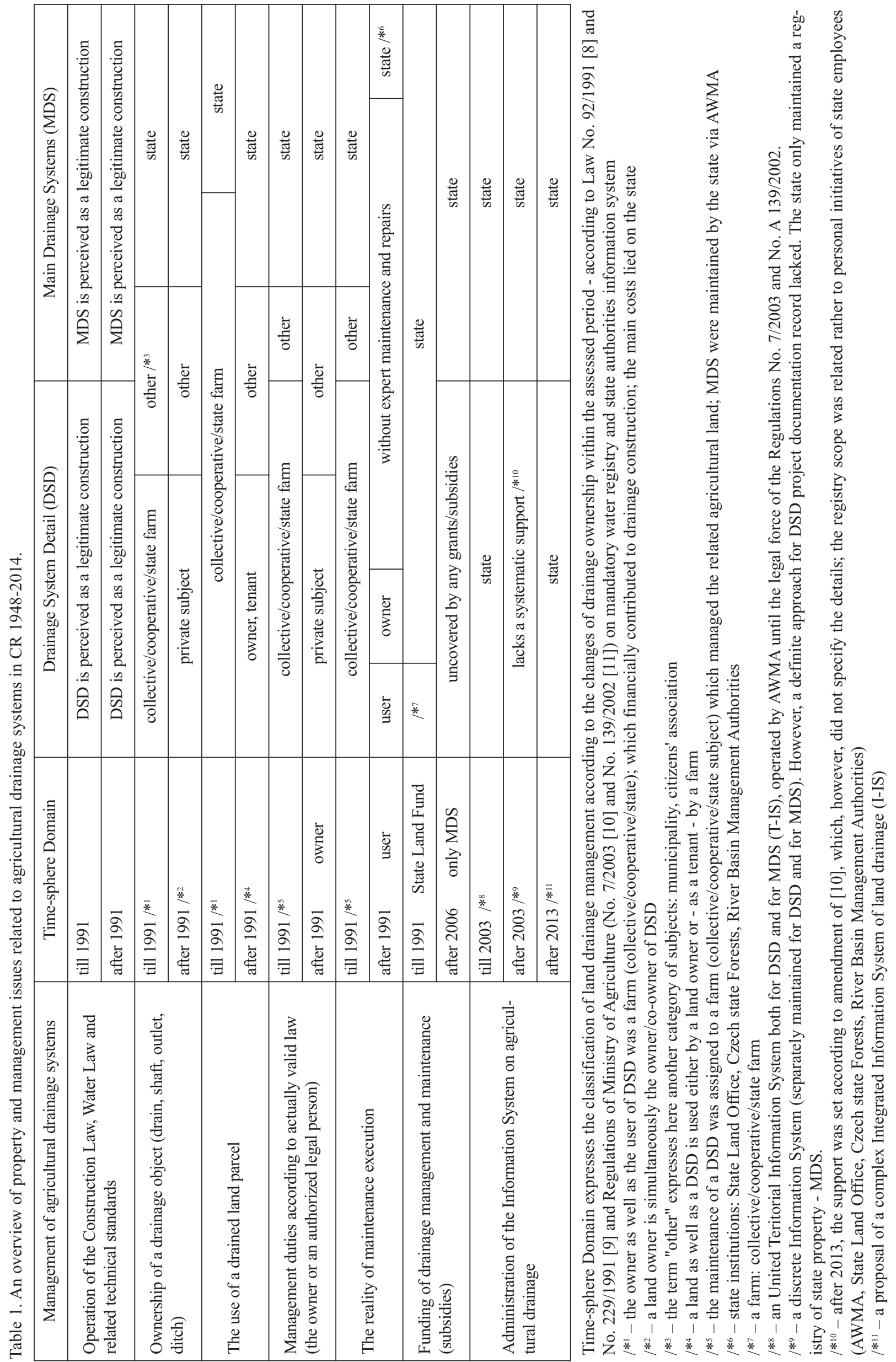


It is evident that we are now at the beginning of a period when we will have to find systematic solutions supporting the sustainable use of agricultural land which, beside other factors, loses its productive capacity due to the decreasing functionality of land drainage. The current period is characterized by dynamic climate change, with growing hydrological extremes such as intensive torrential precipitation or long-lasting droughts. The scenarios of climatic changes for Central Europe [15] presume air temperature increases, elevated evapotranspiration (ET) and, consequently, decreases of summer mean and minimal discharges [16]. We can see the negative impacts of these phenomena as frequent inundations, floods, erosive processes, or dramatic drops of water resource supplies. This will require changes in management of water resources in order to enhance accumulation and retention of water, optimally already in soil or in suitable watershed zones [17, 18], emphasizing also the significance, versatility, and potential of the drainage systems. In some cases, the importance of drainage systems was rather underestimated and not adequately appreciated in CR and abroad. Nevertheless, properly maintained agricultural drainage systems should be considered as a factor playing an important role in both food safety and management of water resources, as well as in environmental protection (as mentioned by $[19,20]$.

More effective agricultural water management is enabled by drainage systems extended by mechanisms for runoff regulation (controlled drainage - CD) [20-22]. Contrary to traditional, one-purpose drainage systems (free drainage), CD systems are more demanding for maintenance. Therefore, some of CD systems built in CR in the past [23] are not functional anymore and new ones have not yet been established [2]. The benefits of these systems from agricultural and water management views have been pointed out by documentation from the 1970s-80s (mostly research reports in Czech) as well as by contemporary studies from abroad $[21,24]$. In addition, CD systems may nowadays be considered as an option to the total elimination of land drainage in places with an apparent unfavourable water balance caused by excess drainage ("overdrainage"), which is being denounced especially in environmentally valuable areas. CD systems involve the use of many types of adjustable, flow-retarding structures placed either in the drainage outlet or in the drainage shafts (manholes) [20, 24].

\section{Assets and Pitfalls of Traditional Land Drainage}

Data available today on agricultural drainage in CR have been gathered in the course of more than 150 years of land draining. This includes the pre-war period $[1,25]$, period of agricultural socialization [26], and the so-far latest period starting from 1990 [2]. Each of these periods is characterized by a specific approach and diverse methods of drainage construction. After 1970, the focus also shifted to research and construction of the above-mentioned twofunctional drainage systems [23] with controlled drainage runoff ( $\mathrm{CD}$ systems). This period may be considered the final stage of the last wave (during 1975-88) of drainage system construction in CR. CD systems were designed to reduce the undue drainage runoff and to support subsurface irrigation [27-30]. The low prices of water and energies in $\mathrm{CR}$ and the main objective of adopted measures - subsurface irrigation - has led to a preferred utilization of "foreign" water (e.g. drawn gravitationally or by pumps from watercourses and reservoirs) instead of retardation of our "own" drainage water. Besides the above-mentioned environmental issue, $\mathrm{CD}$ could be a suitable option in periods when the ongoing uncontrolled drainage runoff reduces soil moisture. This has consequent effects on lowering groundwater levels in deeper groundwater bodies [21].

As a consequence, especially in drier years, water stress and elevated local warming of the environment may increase $[31,32]$. These effects can be mitigated by adequate regulation of drainage runoff, which help to increase soil water content in the periods of water shortages and so optimize crop yields while the draining functions of the system are retained [21, 33, 34].

The issue of water quality from agricultural drainage systems (both tiles and ditches) has been initiated by studies showing the decreasing quality of drainage waters caused by elevated concentrations of nutrients $(\mathrm{N}, \mathrm{P}, \mathrm{C})$ and pesticides. Reports have shown results of direct monitoring of drainage groups or very small drained catchments [3542]. Moreover, various model approaches quantified the contribution of agricultural drainage to water pollution in larger areas as non-negligible [3, 43-46]. In principle, land drainage increases aeration of soil profile and thus promotes mineralization of organic matter and reduces denitrification in previously waterlogged soils. In this way, drainage elevates leaching of nitrates, carbon, and potentially some soluble, non-sorbing pesticides, namely under arable land with lighter soil texture [3, 36, 39, 42].

Phosphorus, both in particulate and dissolved forms, as well as sorbing pesticides, enter the drainage systems namely through preferential pathways of various types and origins in medium-heavy and heavy soils. In lighter-textured soils, the sorption capacity is usually low, but rapid water movement though soil profile may occur, too. Both the phosphorus forms are then lost mostly during rainfallrunoff events [24, 40, 46-48]. On the other hand, there is evidence on the positive effects of land drainage on water quality, especially through the reduction of surface runoff and associated erosive processes, as documented by, e.g., [21] and [49]. However, the matter of water quality as well as quantity related to agricultural drainage systems needs to be taken into account when approaching the targets, set by European Directives dealing with water environment [5052].

\section{Options for Regulation of Drainage Runoff and Enhancement of Drainage Water Quality}

The aforementioned findings led to the study of effects of diverse adaptation options or measures (technical, biotechnical, organizational, agro technical, or their combinations) for improving the quality of water coming from tile and surface agricultural drainage systems. Well known are 
studies that report different types of controlled drainage and its positive effects on reducing drainage runoff and mitigating solute concentrations both in tiles and surface drainage ditches [22, 24, 34, 39, 53, 54]. Other measures for improving drainage water quality include various denitrification bioreactors, constructed or natural wetlands, changes in fertilization and tillage management, planting of catchcrops, or grassing the drained land [55-62]. In short, the efforts principally aim to:

i) Decrease the input of nutrients or plant-protective compounds from soil to water and promote the natural processes of binding the nutrients in soil (reducing mineralization of organic matter, increasing denitrification, augmenting sorption)

ii) Enhance water retention time in soil and thus increasing the consumption of nutrients by plants or soil biota. A number of these approaches have been introduced into agricultural practice (e.g. in New Zealand [60], the UK [63], the USA [64]). From the gained experience it is obvious that the aspect of water quality must be definitely respected during any intervention concerning agricultural drainage systems [65]. Reported effectiveness of the measures lies in general in a reduction of drainage runoff and preservation (or even elevation) of crop yields (controlled drainage and sub-irrigation) and high effectiveness in nitrate nitrogen removal (the majority of measures), while the effectiveness of many measures aimed at reduction of phosphorus is ambiguous $[24,33,54,60]$.

The present situation of agricultural drainage systems in CR may paradoxically provide, due to the current state of their maintenance or need for more extensive repairs, an opportunity to reassess the function of agricultural drainage in the landscape and to consider its additional adaptations. This hypothesis has inspired our work. The systems may only need simple repairs on the one hand, but on the other, extensive modernization may be needed with additional adaptations regulating the drainage runoff or transferring drainage water from the sites of its abundance to the sites of its deficit, i.e., to locations suitable for infiltration [66, 67]. Finally, there are obviously landscape enclaves, artificially drained in the past, with prevailingly other than agricultural interests. Here, the following aspect should be taken into account: diversification of moisture regimes for promoting biological diversity of the landscape or for enhancing the natural nutrient or pollutants attenuation processes. In such landscape zones, we may consider partial or total elimination of the existing drainage systems [31, 59].

\section{Material and Methods}

\section{Mapping the Effects of Drainage System Management}

The principles of agricultural drainage system construction in CR and the historical context forming their present condition were described in the Introduction. Changes in the management of these systems observed in the previous 25 years and reported in this paper were documented based on field investigations. These surveys, done on 39 different tile-drained areas in CR (Fig. 1), were focused on inquiry of drainage systems state and exploitation within various research projects and studies funded mostly by the CR Ministry of Agriculture. This study is therefore a summary of the results gained in the past.

These results were often obtained by diverse methodologies, yet we aimed to synthesize them for critical analysis of the present conditions and justification for drainage existence. The main tool for identification of agricultural land blocks, for information on land use, and for identification of farmers was the LPIS (Czech Land Parcel

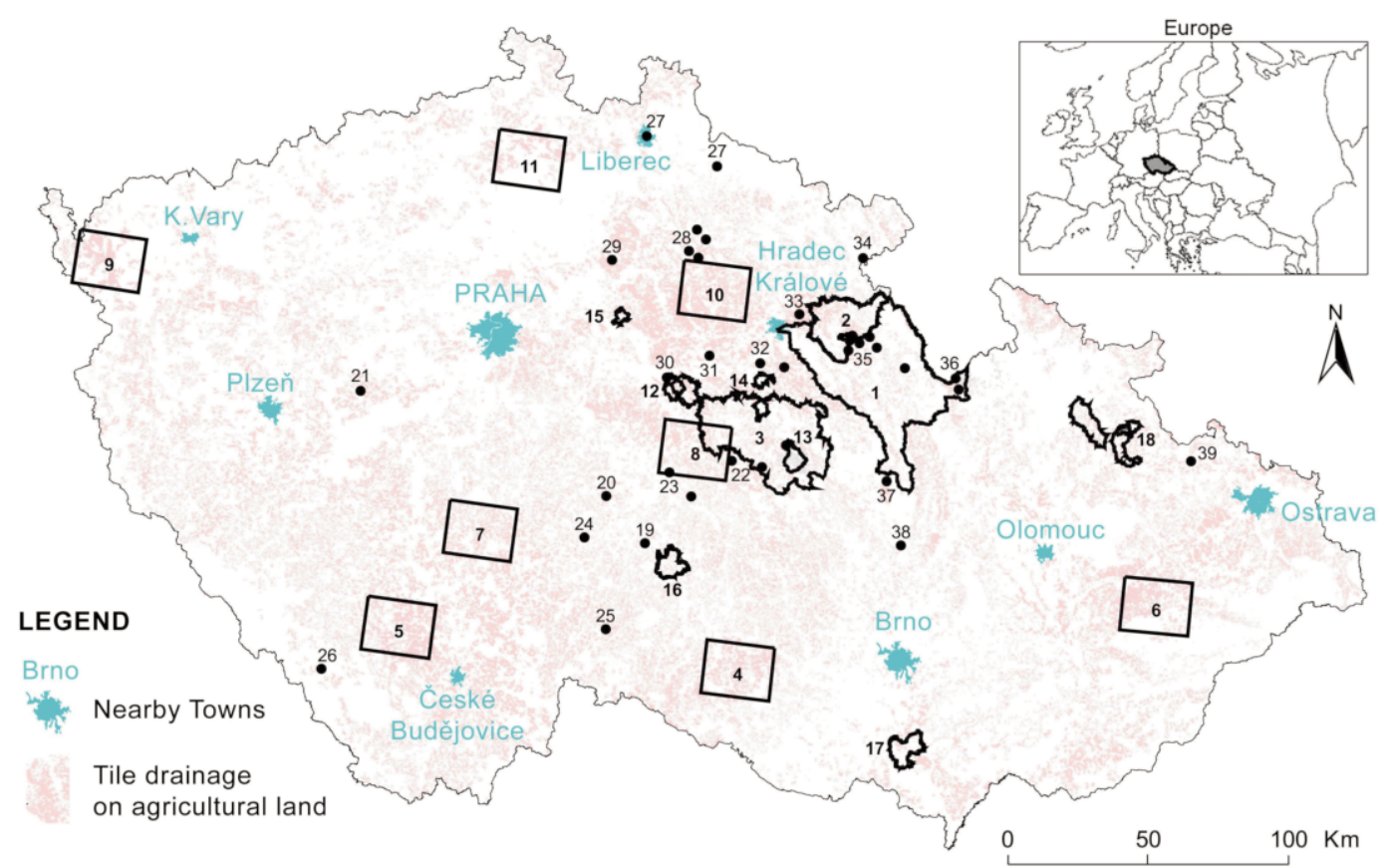

Fig. 1. An overview map of model areas within the CR. The description of model areas and applied approach are displayed in Table 2. 
Table 2. An overview of analyzed areas.

\begin{tabular}{|c|c|c|c|c|c|c|}
\hline \multirow{2}{*}{$\begin{array}{l}\text { No. of } \\
\text { location }\end{array}$} & \multirow{2}{*}{ Location } & \multicolumn{5}{|c|}{$\begin{array}{c}\text { Used methods of diagnostics (see section Evaluating the Present State and } \\
\text { Defect Causes of Land Drainage Systems) }\end{array}$} \\
\hline & & a) & b) & c) & d) & e) \\
\hline 1 & the Orlice River basin & $*$ & * & * & $*$ & $*$ \\
\hline 2 & the Dědina River basin & $*$ & & & & $*$ \\
\hline 3 & the Chrudim District & $*$ & $*$ & $*$ & $*$ & $*$ \\
\hline 4 & region Moravské Budějovice & $*$ & & $*$ & $*$ & $*$ \\
\hline 5 & region Vodňany & $*$ & & * & $*$ & $*$ \\
\hline 6 & region Hranice nad Moravou & $*$ & & $*$ & $*$ & $*$ \\
\hline 7 & region Milevsko & $*$ & & * & $*$ & $*$ \\
\hline 8 & region Č́áslav/Golčův Jeníkov & $*$ & $*$ & $*$ & $*$ & $*$ \\
\hline 9 & region Cheb/Mariánské Lázně & $*$ & & $*$ & $*$ & $*$ \\
\hline 10 & region Hořice & $*$ & & * & $*$ & * \\
\hline 11 & region Česká Lípa & $*$ & & $*$ & $*$ & * \\
\hline 12 & Kačina & $*$ & $*$ & * & & * \\
\hline 13 & the Žejbro River basin & $*$ & $*$ & * & $*$ & $*$ \\
\hline 14 & Pardubice & & & & $*$ & $*$ \\
\hline 15 & the District Nymburk & * & & & $*$ & * \\
\hline 16 & the Hubenov Region & $*$ & & & $*$ & \\
\hline 17 & the Hustopeče Region & $*$ & & & $*$ & \\
\hline 18 & three subbasins in the Opava River basin & $*$ & & & & \\
\hline 19 & the Kopaninský Brook basin & $*$ & $*$ & & & $*$ \\
\hline 20 & Černičí & $*$ & $*$ & * & $*$ & * \\
\hline 21 & the Cerhovický Brook basin & $*$ & $*$ & * & $*$ & $*$ \\
\hline 22 & Maleč, Kvasín and Dřevíkov & $*$ & $*$ & * & $*$ & $*$ \\
\hline 23 & Valečov and Ovesná Lhota & $*$ & $*$ & & & * \\
\hline 24 & Pacov & & & * & & $*$ \\
\hline 25 & Česká Olešná & * & & * & $*$ & * \\
\hline 26 & Lenora & $*$ & & * & $*$ & $*$ \\
\hline 27 & the District Liberec and Jablonec nad Jizerou & $*$ & & & & \\
\hline 28 & drainage systems in the Jičín District & * & & & & $*$ \\
\hline 29 & Dobrovice & $*$ & & & & $*$ \\
\hline 30 & Starý Kolín & $*$ & $*$ & & & $*$ \\
\hline 31 & Kolesa - Vápno & $*$ & $*$ & & $*$ & $*$ \\
\hline 32 & Srch and Choteč (the District Pardubice) & $*$ & $*$ & & & $*$ \\
\hline 33 & Černilov & & & & $*$ & $*$ \\
\hline 34 & Křepelka & & * & & & $*$ \\
\hline 35 & drainage systems in the Rychnov District & $*$ & * & * & $*$ & * \\
\hline 36 & the Lipkovský Brook basin (region Králíky) & $*$ & $*$ & * & $*$ & * \\
\hline 37 & the District Svitavy & * & & & & \\
\hline 38 & Meziříčko & * & & & & $*$ \\
\hline 39 & the Petrův fishpond (Opava) & & & & & * \\
\hline
\end{tabular}

Table heading (a-e) shows applied methods or approaches. $(*$ the method was applied) 
Identification System; a database connected with GIS Internet interface for information of agricultural land parcels in the CR). Some applied approaches are also being employed within the long-term monitoring of experimental localities, focused on augmenting water retention and accumulation in agricultural landscape and on improving drainage water quality [37, 38, 68, 69].

Model areas used in our paper are shown in the map of CR in Fig. 1.

Taking into account the linkages between property and management issues of land drainage in CR as described in Table 1, the following aspects were analyzed:

A. The role of land parcel owner and after 1991 also of the owner of DSD, when Act No. 92/1991 [8] and Act No. 229/1991 [9] brought restitution of the land ownership by physical entities (restoration of the original legal state), with consequent transfer of the state property (MDS) to other entities.

B. The role of land parcel user (typically an agricultural subject; the roles and competences differ between before or after 1991). The land parcel user is either acquainted with the land history (arising as a successor of the previous cooperative working in the locality), or newly entered the land. This fact is particularly important in relation to the condition and parameters of a drainage system.

C. The role of the administrator of land drainage database and T-IS. Until 1991 the evidence of drainage investment costs was merged with the investment activities of AWMA. After 1991, with restitution of land and of DSD, the evidence of state property was separated and the T-IS was adapted for its administration. The T-IS operation was provided by AWMA by assignment as administrator of the particular T-IS component and as part of its water-legislation organ tasks. However, the factual definition of this part was vague and the evidence of DSD was done according to custom practices rather than to a precise definition. After 2012, when the AWMA was abolished, the conditions further changed.

D. The role of MDS administrator: AWMA. Until 2012 the MDS administrator also acted as the administrator of the archives of project documentation of land drainage, but later these functions were transmitted to state companies (River Basins Administration Enterprises, Czech Forests), or - after 1 January 2013 - the Czech State Land Office. At present, MDS is administered by the state via Czech State Land Office; according to the water course character and local incidence, some sections were transferred to state companies (River Basins Administration Enterprises, Czech Forests) or to the municipalities.

E. The role of the state in formulating (any kind of) support for land drainage at the level of the Ministry of Agriculture and Ministry of Environment (both national and EU levels).

F. The anticipated role of the association of drained land parcel owners ("water cooperatives") in administration predominantly of the common property or its design in the case of new construction (access road, drainage ditch, water regime of a broader land area, etc). So far, the vanished water cooperatives have not been restored.

G. Factual reasons or motives for reassessment of the drainage system functions in a landscape. This includes the aspects of system age, the manner of performed maintenance and repairs, the incidence and consequences of droughts, or periods of inadequate drainage water quality and environmental protection interests.

The investigation performed in the localities shown in Fig. 1 took into account the management both of DSD and MDS, according to the above-mentioned aspects of the existence and the anticipated functioning of agricultural drainage systems in the landscape. Some aspects (F, G) have only been considered hypothetically to document their benefit if applied in practice. Others $(\mathrm{B}, \mathrm{D})$ are dominant within all aspects. Still others (A, C, E) play a role in specific situations only (the need for more extensive repairs, changes in land use, etc.) and are practically negligible in routine situations.

The numbers of drainage system unit owners (recalculated to $1 \mathrm{ha}$ ) for select areas of CR are given in Table 3 .

\section{Evaluating the Present State and Defect Causes of Land Drainage Systems}

The present state of land drainage systems in CR has never been systematically monitored. Therefore, there exist no comprehensive materials describing the condition and functionality of agricultural drainage systems concerning the requirements for repairs and maintenance, (according to [70]) or determination of the optimum range of adaptations on these systems. In our work, we therefore used model localities for investigating the required purposes (see indices used in Fig. 1). These localities provide a general survey of the state and condition of drainage systems in CR. More detailed surveys preferentially focused on the localities with more apparent defects.

The diagnostics of assessed drainage systems and description of the reasons for their failure was done using the following methods (Table 2):

a. The use of archival documentation (especially when the project documentation for a drainage system was available), territorial studies related to a drainage system and describing its state: location of the system, its objects and parts, analysis of natural conditions of the locality (soil surveys dating from the time of the system design)

b. Our own field survey at both MDS and DSD: terrain recognition, location of drainage system objects, description of their state (using diagnostic devices, such as hand GPS, pipeline camera, etc.)

c. A methodologically inhomogeneous discussion with land users and owners and other persons familiar with the locality (e.g. people remembering the construction of land drainage, its designers, etc.): using the users' knowledge of the drainage functioning, their perception of the required changes, specification of the drainage system, etc.

d. The use of aerial photographs (Fig. 2), usually geo-referenced for use in GIS (with distinctly displayed 


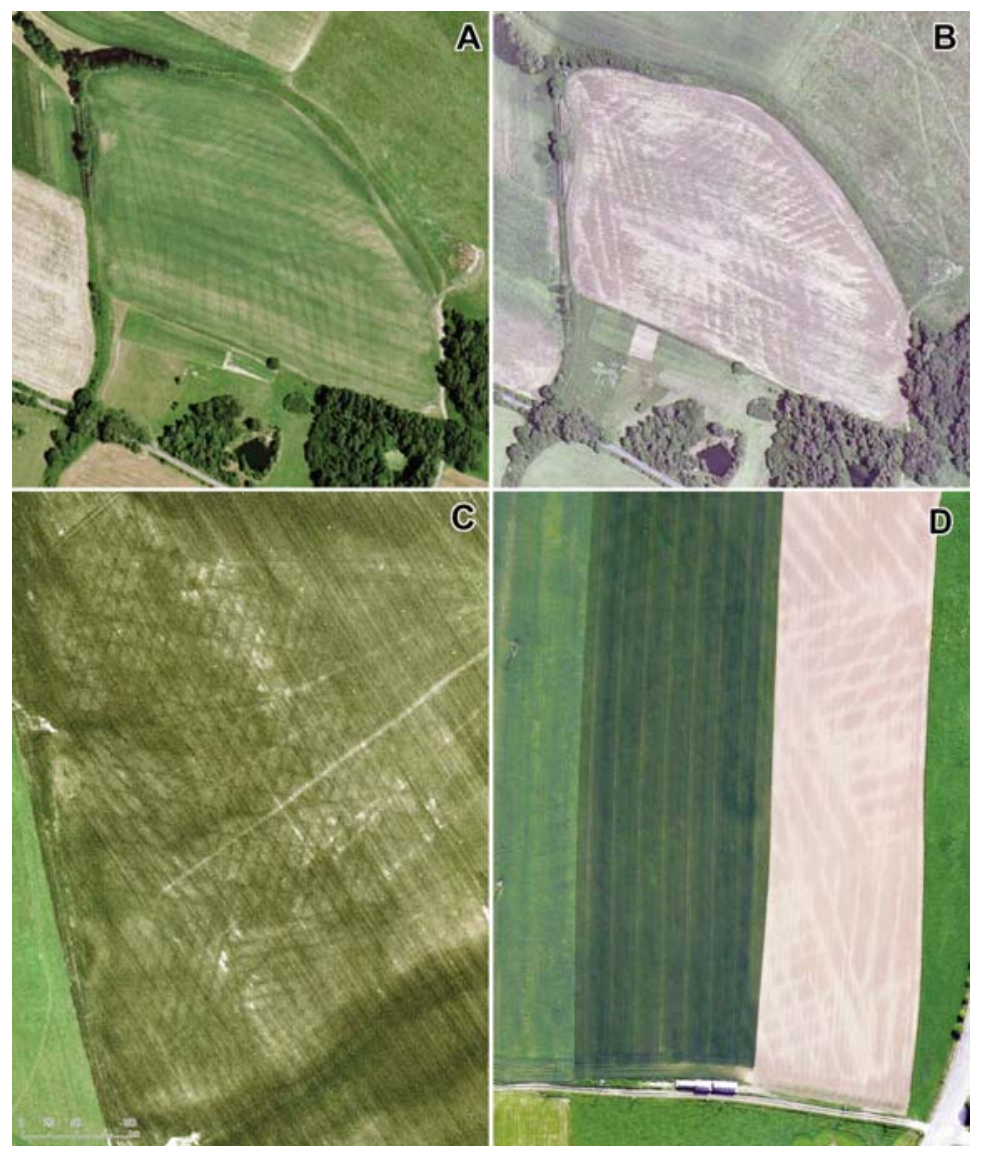

Fig. 2. An example of the use of remote sensing for localizing underground agricultural drainage elements and for identification of the existence and condition of drainage systems. All pictures show different manifestations of functional land drainage: phyto-indicative $(A, C)$ and differences in surface moisture during soil drying $(B, D)$. Identification of two overlaid drainage systems one on another (C, D). [A, B: Kvasín; C: Maleč; D: Mrákotín].

drainage systems). Methods of remote sensing used for the identification of drainage systems were described e.g. by [71-73]. To classify the visualization of a drainage system on aerial photos according to the accuracy and surface area, we used the five following categories:

1) Surface-integrated system, clear identification

2) Non-integrated system, clear identification
3) Disjointed parts (up to $50 \%$ )

4) Disjointed parts (up to 50\%), unclear

5) Disjointed, poorly visible, isolated parts

The acquired empirical data were processed in GIS, which enabled us to describe in a larger territorial context the problematic enclaves or drainage systems with various types of defects. Field locations of the enclaves with defects were done either directly by the land users or by the land owners.
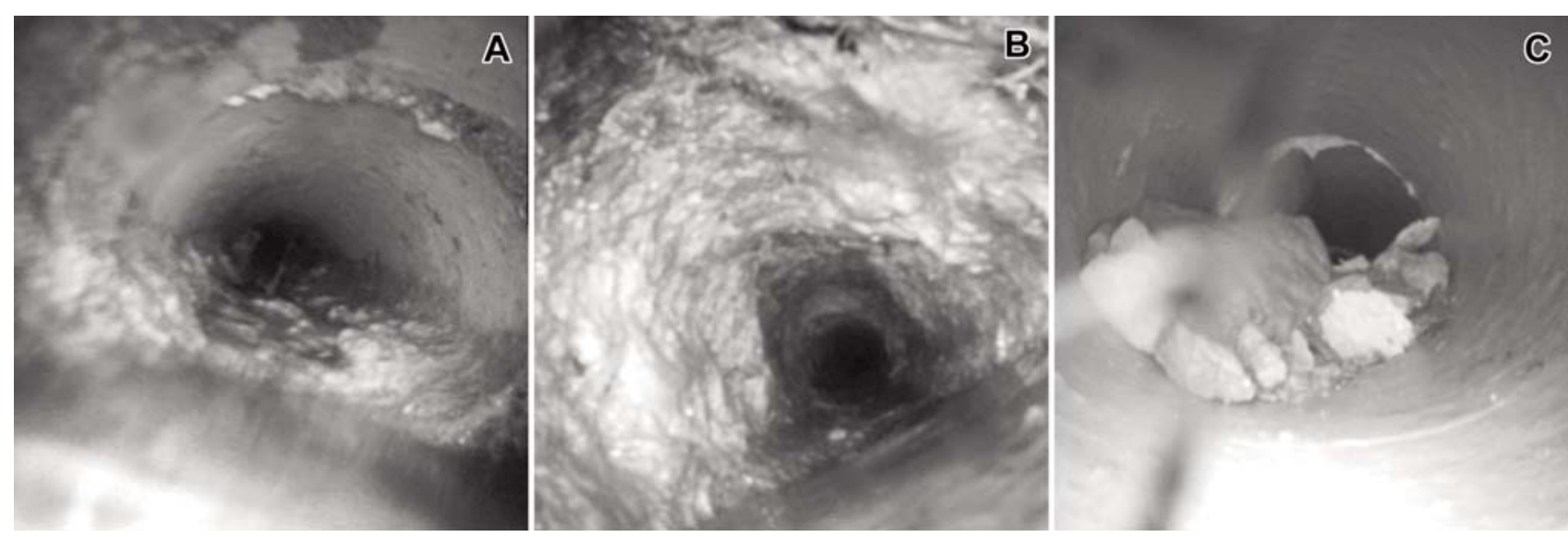

Fig. 3. Documentation of the drainage pipe condition using the inspection camera. From the left: clogging of the flow drainage profile with accumulated fine sediments, incrustation of iron compounds on tile walls, local blocking of the tiles by tile fragments, and rough sediment material. 


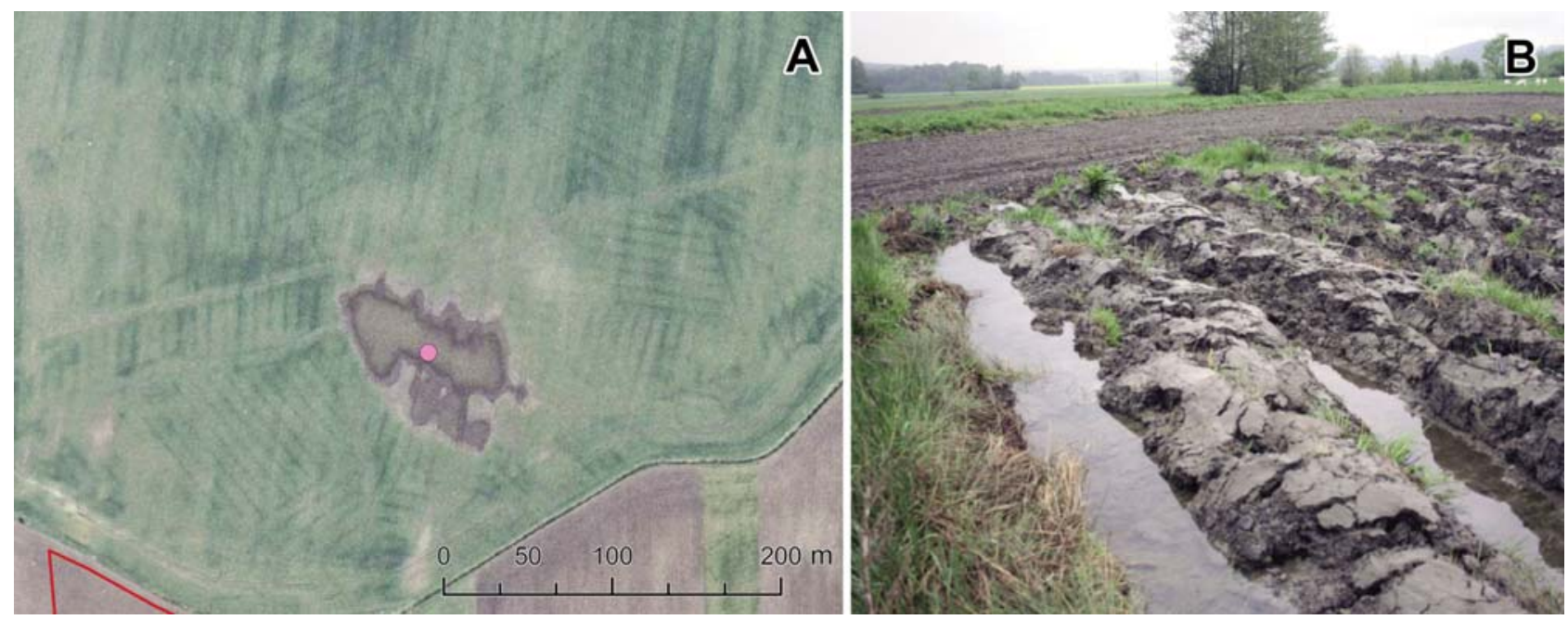

Fig. 4. Examples of identifying a drainage system defect (left: using remote sensing methods, right: the same defect examined by land survey).

The survey was done using remote sensing methods: screening and recording of waterlogged localities and drainage failures, changes in land use using time-lapse photographs (usually with a three to five year's time-span), and also an active search for visible drainage systems aimed at verification of the project design and documentation or its amendment.

e) Field survey of the drains and their state, description of the drainage groove and the surrounding original terrain and soil properties (measurement of differences in soil hydro-physical properties), characterization of hydraulic properties of the drain inlet area with the aim to propose an effective elimination measure. We used a Rothenberger inspection tile camera with $30 \mathrm{~m}$ scope (Fig. 3). It is a non-destructive survey method for determination of the present state of drains. The applicability and results of this survey are relatively good when it is accomplished from the drainage outlets or drainage wells upwards to drains. The inspection camera can also be used in a dug soil probe after drain exposure.

The functionality, state and defects of the drainage systems (Fig. 4) were described using the following aspects:

- A defective function of main drainage system (MDS) mainly open ditches or buried pipes

- A defective function of a drainage detail (DSD) - of a part of the conducting drain and objects on the conducting drain (control shafts, etc)

- Increased exploitation of the drained land. The opposite cases (when the draining intensity of a land parcel exceeds the current requirements for farming) were not assessed from the agricultural point of view as functional failures, even though they should be considered inadequate from the aspects of water and environmental protection

- A functional failure of a drainage detail - individual drain or group of collecting drains

- A change in hydro-physical soil properties (subsoil compaction, formation of impermeable horizon, e.g. by colmatation of soil particles or by precipitation of mineral or organic soil components)
- A change in the components of hydrological balance in the drained land parcel (by increased inflow of surface or groundwater from adjoining localities - potentially caused by land use change in adjoining land parcels, inadequate tillage, or by failures on various water management structures)

- A change of climatic conditions (more frequent periods with abundant precipitation)

\section{Criteria to Maintain or to Change the Functions of Drainage Systems}

Agricultural drainage typically consists of a collection of partial components (structural objects) forming a complete functional unit (see Introduction: DSD and MDS). Changes in the parameters of one of its structural part may impact the functioning of another part. In case the requirements for drainage functioning on a land parcel remain constant (i.e. they are identical to those in time of drainage construction), the repairs and maintenance will be aimed at restoring the drainage. This strategy will be supported by the Czech governmental adjustment of agricultural policy made in spring 2014, pointing out the need to increase state nutritional safety. This is directly associated with soil productive functions, and so too with the state of agricultural drainage.

However, if the requirements for the particular land parcel use have changed, or the priority has locally been turned to non-productive functions (nature conservation, protective management within drinking water zones, etc.), elimination or removal of a drainage system or its part shall be considered.

In theory, elimination measures on land drainage are not substantially limited, and the proposal is mainly assessed in view of its implementation limits. Surveys describing the state of the concerned area before the drainage implementation are valuable for this purpose, defining the reasons of waterlogging and the need for drainage intensity. This information is contained in the project documentation of the drainage system. The impact of elimination measures 
Table 3. Number of land parcels (owners) included in a drainage system recalculated to one hectar (see column "Number"). The average area of drained land per a farm in CR is about 20 ha.

\begin{tabular}{|l|c|c|c|c|c|c|c|c|}
\hline \multicolumn{1}{|c}{$\begin{array}{c}\text { Selected areas/ } \\
\text { section }\end{array}$} & $\begin{array}{c}\text { Section area/* } \\
\text { [ha] }\end{array}$ & $\begin{array}{c}\text { Numbers of } \\
\text { drainage } \\
\text { unit/structure }\end{array}$ & $\begin{array}{c}\text { Drained area } \\
\text { [ha] }\end{array}$ & $\begin{array}{c}\text { Average area } \\
\text { of a drainage } \\
\text { structure [ha] }\end{array}$ & $\begin{array}{c}\text { Portion of } \\
\text { drained area on } \\
\text { section [\%] }\end{array}$ & \multicolumn{4}{|c|}{ Mumber } \\
\cline { 5 - 9 } d. Chrudim [3] & $2,171.1$ & 57 & 231.57 & 4.1 & 10.7 & 0.2 & 13.1 & 4.1 \\
\hline d. Jablonec [27] & $8,695.7$ & 13 & 75.39 & 5.8 & 0.9 & 1.5 & 18.5 & 4.8 \\
\hline d. Liberec [27] & $4,346.9$ & 39 & 744.36 & 19.1 & 17.1 & 0.2 & 19.9 & 6.7 \\
\hline d. Nymburk [15] & $1,660.2$ & 54 & $1,284.26$ & 23.8 & 77.4 & 0.5 & 24.6 & 3.0 \\
\hline d. Svitavy [37] & $3,851.8$ & 38 & 181.91 & 4.8 & 4.7 & 1.1 & 19.9 & 4.3 \\
\hline d. Pardubice [32] & $5,113.4$ & 93 & $1,253.13$ & 13.5 & 24.5 & 0.3 & 16.8 & 4.7 \\
\hline b. Žejbro [13] & $8,618.0$ & 232 & $2,639.0$ & 11.4 & 30.6 & 0.30 & 101.7 & 8.3 \\
\hline r. Cheb [9] & $61,359.7$ & 377 & $9,429.0$ & 25.0 & 15.4 & 0.04 & 20.5 & 2.1 \\
\hline r. Vodňany [5] & $45,430.3$ & 717 & $14,115.4$ & 19.7 & 31.1 & 0.19 & 73.1 & 4.6 \\
\hline r. Třebíć [4] & $35,411.7$ & 1,099 & $6,640.3$ & 6.0 & 18.8 & 0.43 & 85.1 & 7.6 \\
\hline r. Králíky [36] & $24,441.2$ & 270 & $3,385.2$ & 12.5 & 13.9 & 0.32 & 46.8 & 5.2 \\
\hline r. Hranice n.M [6] & $48,811.0$ & 775 & $9,808.3$ & 12.7 & 20.1 & 0.37 & 38.6 & 6.5 \\
\hline r. Česká Lípa [11] & $49,264.1$ & 360 & $6,953.9$ & 19.3 & 14.1 & 0.30 & 84.5 & 4.2 \\
\hline
\end{tabular}

Numbers in the brackets corresponds with the numbering of model areas depicted in Fig. 1.

d. - district, r. - region, b. - basin

$/ *-$ An area of a section with available digitized cadastral maps

can thus be better quantified. The design of such measures must be substantiated by an evidence showing that no or very little subsequent investments will be required (both on the particular land parcel and the surrounding land parcels or drainage structures). The effectiveness of an adaptation or of a measure itself can be evaluated by comparing its anticipated effect on reducing the drainage runoff and its proportion in the total runoff from a particular territory. This should be based on field surveys aimed at determining the drainage runoff conditions and land use and management manners, or optionally at establishing additional parameters for assessment of the expected effects.

The adaptations of drainage functions or the proposal to eliminate measures should be prepared in multiple variants in order to achieve the optimum solution based on the comments of all interested persons and subjects. Preparation of this proposal consists of:

- the concept of the target drainage state and the prerequisites for its achievement. This is particularly suitable for simpler situations, with a low number of external relationships and criteria;

- in complex situations, more sophisticated methods should be employed (e.g. multi-parameter analyses), enabling processing and comprehensive assessment of the multilayered parameter system and of the solution variants and, along with the optimum ranking of the variants, mutual comparison of their value.

As an example for simpler situations, a diagram was prepared considering the most frequent requirements from the practice, given in Tables 4 and 5 .
Selection of the adequate type of elimination options and measures respected the following aspects:

- The existing negative aspects of land drainage in a particular locality with delineation of the potential functional relationship with neighbouring land parcels and parts of the drainage system (type and intensity of land use, owner-user relationships)

- Types of possible elimination measures according to the List of Measures (Table 4) with respect to drainage objects (shafts, ditches, tiles, etc.) located on the drained land

- The investor's/owner's objective regarding any of the possible elimination measures on a drainage system the capacity to cover the expected costs (a measure purchase and operation), and options for possible funding

- Technical limits of the suitable elimination measures according to soil and slope characteristics with respect to areal parameters, in connection with hydrological and hydraulic parameters of drainage systems and related environmental aspects

\section{Results and Discussion}

\section{Conditions for Applying New Approaches}

The complex analysis of ownership relationships and of the parameters and state of drainage systems showed considerable heterogeneity of the investigated factors in the model localities. This was due to the aspects described in 
Table 4. A recommended approach for the selection of suitable elimination measure on agricultural drainage system (measures given in lines). Values in columns are set up according to the particular drainage system conditions and express the criteria for fulfilling the condition of the measure to fully fit the definition (in case of 1.0 value) or not fitting it (in case of 0 ).

\begin{tabular}{|c|c|c|c|c|c|c|c|c|c|c|}
\hline & $\begin{array}{c}\text { Decision Criteria (see Table } 5 \text { for explanation) } \\
\text { List of Measures }\end{array}$ & 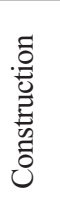 & 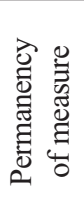 & 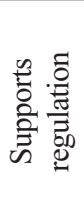 & 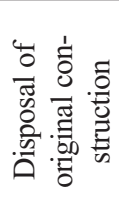 & 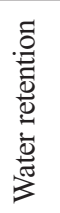 & 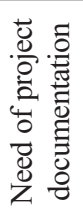 & 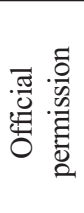 & 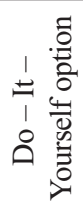 & 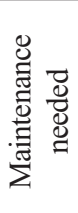 \\
\hline \multirow{11}{*}{ 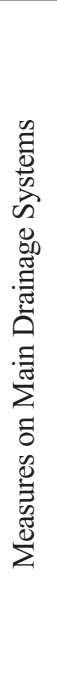 } & Uncover tubed main drainage systems (MDS) & 1.0 & 1.0 & 0 & 1.0 & 0.3 & 1.0 & 1.0 & 0.3 & 0.3 \\
\hline & $\begin{array}{l}\text { Changes of original MDS design parameters } \\
\text { (elevation+direction alterations) }\end{array}$ & 1.0 & 1.0 & 0.7 & 1.0 & 0.7 & 1.0 & 1.0 & 0 & 0.3 \\
\hline & Transfer of waters at the level of MDS & 1.0 & 1.0 & 0.7 & 0.3 & 1.0 & 1.0 & 1.0 & 0.3 & 0.3 \\
\hline & Regulation of waters at the level of MDS & 1.0 & 0.7 & 1.0 & 0 & 1.0 & 0.7 & 0.7 & 0.7 & 0.7 \\
\hline & Elimination of drainage pumping objects & 1.0 & 1.0 & 0 & 1.0 & 1.0 & 1.0 & 1.0 & 0.3 & 0 \\
\hline & Controlled spontaneous ageing of drainage & 0 & 0.7 & 0 & 1.0 & 0.7 & 0.3 & 0 & 1.0 & 0.3 \\
\hline & Aforestation of agricultural land & 0.3 & 1.0 & 0 & 0.7 & 0.7 & 0 & 0.3 & 1.0 & 0.7 \\
\hline & Permanent grassing of agricultural land & 0 & 0.7 & 0 & 0 & 0.7 & 0 & 0 & 1.0 & 1.0 \\
\hline & Regulated drainage rooting (by shrubs and herbs) & 0 & 0.7 & 0 & 0.7 & 1.0 & 0.3 & 0 & 1.0 & 0.3 \\
\hline & Overland flow control (use of anti-erosion measures) & 0.7 & 0.3 & 0 & 0 & 0.7 & 0.7 & 0 & 0.3 & 0.7 \\
\hline & $\begin{array}{l}\text { Placing a contoured buffer strip (grass, shrubs) for reduction } \\
\text { of drainage intensity }\end{array}$ & 0 & 0.7 & 0 & 0.3 & 0.3 & 0.7 & 0.3 & 0.7 & 0.3 \\
\hline \multirow{12}{*}{ 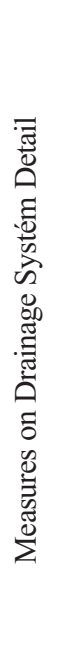 } & Elimination of collective drain effect & 1.0 & 1.0 & 0 & 0.7 & 1.0 & 0.7 & 0.3 & 0.3 & 0 \\
\hline & Local elimination of a part of collective drain (tile) & 1.0 & 1.0 & 0 & 1.0 & 1.0 & 0.7 & 0.3 & 0.7 & 0 \\
\hline & Uncover collective drain and its disposal & 1.0 & 1.0 & 0 & 1.0 & 1.0 & 1.0 & 1.0 & 0 & 0 \\
\hline & Interrupt of tile's part & 1.0 & 1.0 & 0 & 1.0 & 1.0 & 1.0 & 0.7 & 0.7 & 0 \\
\hline & Blind plugs on collective drains (tiles) & 1.0 & 1.0 & 0 & 0.7 & 1.0 & 1.0 & 0.3 & 0.3 & 0 \\
\hline & Regulation of waters at the level of DSD & 1.0 & 1.0 & 1.0 & 0 & 1.0 & 1.0 & 0.7 & 0.3 & 0.7 \\
\hline & Curtain on collective drain (tile) & 1.0 & 1.0 & 1.0 & 0 & 1.0 & 1.0 & 0.3 & 0.3 & 0.3 \\
\hline & Subsurface water retardation in tiles & 1.0 & 1.0 & 1.0 & 0 & 1.0 & 1.0 & 1.0 & 0 & 0.3 \\
\hline & Transfer of waters at the level of DSD & 1.0 & 1.0 & 0.7 & 0 & 0.7 & 1.0 & 1.0 & 0.3 & 0.7 \\
\hline & Disposal of spring sump and renewal of spring & 1.0 & 1.0 & 0 & 1.0 & 1.0 & 1.0 & 1.0 & 0.3 & 0 \\
\hline & Disposal of spring sump - wetland/pool establishment & 1.0 & 1.0 & 0.3 & 0.7 & 1.0 & 1.0 & 1.0 & 0 & 0.3 \\
\hline & Regulation of spring sump runoff accompained by grassing & 1.0 & 1.0 & 1.0 & 0.3 & 1.0 & 0.7 & 0.7 & 0.3 & 0.7 \\
\hline
\end{tabular}

Table 5. Explanation of criteria and their preferences given in Table 4.

\begin{tabular}{|l|l|}
\hline \multicolumn{1}{|c|}{ Criteria } & \multicolumn{1}{c|}{ Detailed criteria explanation } \\
\hline Construction & Measure is based on construction/building alterations of currect drainage system \\
\hline Permanency of measure & Measure effect is permanent (by doing a regular maintenance) - the measure effect is not temporary \\
\hline Supports regulation & $\begin{array}{l}\text { Measure enables regulation of drainage water runoff or regulation of drainage intensity (waterlogging } \\
\text { in time and areal extent) }\end{array}$ \\
\hline Disposal of original construction & By adopting a measure, the original drainage construction is disposed \\
\hline Water retention & Measure enhances water residence time in a landscape \\
\hline Need of project documentation & Measure requires original documentation of land drainage design and realization \\
\hline Official permission & $\begin{array}{l}\text { Realization of a measure requires a permission from State Legal Office (Water management branch/ } \\
\text { Department of Environmental Protection) }\end{array}$ \\
\hline Do- It-Yourself option & Measure can be designed and realized by Do-It-Yourself approach \\
\hline Maintenance needed & $\begin{array}{l}\text { To retain the original measure effectiveness, a special care is needed (above the common mainte- } \\
\text { nance level) }\end{array}$ \\
\hline
\end{tabular}


Material and Methods. The investigations on both agricultural practice and state administration subjects confirmed the hypothesis formulated in the Introduction, which described the present period as the distinctive one, anticipating the synergy of natural, technical, and social conditions with the aim to reassess the functions of agricultural drainage in the landscape. The analyses made thus revealed the following topics:

- Water management within drained land parcels enabling regulation of the redundant runoff component and reduction of soil moisture deficit, i.e. elevation of a catchment's retention capacity

- Maintenance and repair of drainage systems, respecting the link between DSD and MDS

- Linkages between surface and drainage water quality

- A need for including maintenance duties in the leases for land parcels containing agricultural drainage systems, as these issues have never been (since 1948) and are not currently included in the leases. This would enable justification of drainage for sustainable agricultural production and, further, would corroborate the appropriate value of drained land.

- Promoting the concept and indispensability of a new Integrated Information System of land drainage (I-IS) $[74,75]$ based on previous T-IS, which would necessarily include a precise placement and parameters of both DSD and MDS as well as soil conservation issues Interconnection of all the above-mentioned aspects (requirements) brought a complete picture of the elimination/regulation measures and options, differing in character and power and in the associated criteria for their application. The proposed set of elimination measures (see Criteria to Maintain or to Change the Functions of Drainage Systems for background) represents the basic types of measures conveniently combined in the practice. They concern either MDS or DSD or both. These measures can be classified according to their quantitative effects into:

- Measures totally eliminating drainage runoff. They are applicable in cases when agricultural drainage as a whole plays a negative role in the landscape - by factors described in Introduction.

- Measures partially eliminating the negative impacts of land drainage. They are applicable in cases when partial drainage is still needed. Partial drainage elimination is provided by runoff regulation while the drainage function is preserved. Among others, the use of water transfers can be employed, in general from locations of its abundance to the locations where it fulfils landscape, water management, or environmental functions.

The results of analyses shown below are structured according to section Mapping the Effects of Drainage System Management.

\section{Ad A-B (role of land parcel owner and land user)}

- The example of fragmented ownership of drained land (Table 3) may serve as an illustrative parallel to the negative effects of excessive fragmentation of land ownership that occurred after 1990 in Central and Eastern
Europe, as shown by $[76,77]$. Such a fragmentation profoundly hampers more complex forms of drainage system maintenance. For instance, the mean area of a drainage group includes the interests of several to tens of owners. This significantly complicates obtaining the owners' consent with proposed changes in drainage system use when applying for state support, as well as in cases of higher investments intended from the user's side. The land user is aware of the risk of potential lease termination from the land owner's side, and minimization of following investments for repairs or measures on land drainage is a consequence. This effect is not as obvious as the described economic pressure on the land lease because land-value decrease due to non-functional drainage is usually not so apparent.

- Investigations among agricultural subjects have confirmed that interest in performing drainage maintenance is directly related to the degree of defect of the drainage system and the costs of repairs. A farmer is willing to perform repairs on the drainage system by himself in the leased land parcel; the repairs usually take place during the period of less field work. The number of repairs can be counted in units per year. The farmer is aware that the goal is to stabilize his own production, but he is also aware of the financial and temporal limits. If the number of requested repairs were to exceed these limits, he would probably consider terminating the land lease.

\section{Ad C (role of T-IS and I-IS administrator)}

Investigations at eight model localities have shown that the transfers of land drainage archive materials were not uniformly coordinated within the $\mathrm{CR}$, causing profound differences between individual regions. When project documentation of land drainage was transferred into archives, records according to the AWMA digital layer that contained the district numbers of drainage systems, year of construction, surface area, etc., were regrettably ignored. In such a situation, another identification factor must be used for finding the particular drainage system (transfer protocol, $1: 10,000$ or 5,000 maps, or knowledge of a former AWMA employee). Although our study was done in the critical period (2011-12), i.e. immediately after the archive material transfer, there still existed many ambiguities. The search for project documentation was revealed as complicated, and some systems documentation exists in various copies in the archives. Some project documentation is incomplete.

This complexity discourages the owners or users of a drainage system from looking for map documentation, and so the repairs are mostly done by the method of "chance and intuition." In many cases this will lead to future damage and problems on agricultural land and even on the hydrologically related vicinity. Optimally, the archive materials should be digitized and the owners provided with electronic accessibility (e.g. via Internet map and archive servers). This is reflected in the proposed I-IS, designed in 2013, which represents a complex system for promoting the productive functions of agricultural land $[74,75]$. However, 
up to the end of 2014 it was only implemented in a limited area (in Králíky - see Fig. 1 and Table 2).

Besides digitization and archiving of the land drainage project documentation, remote sensing tools are used to identify underground objects of the drainage elements [72], [78]. The results primarily serve for verification of the method of execution of the project documentation, and for promoting maintenance and repair, and in future we expect its methodological employment in I-IS implementation.

\section{Ad $D$ (the role of $M D S$ administrator)}

De jure (by the Law from 1991 [8]), the drainage systems were divided into MDS and DSD. Because the major part of MDS still belongs to the state, the state also operates as its administrator (via the State Land Fund, River Basin Administration Authorities, Czech state Forests). Conversely, DSD mostly belongs to a private owner (at the local level also to the state, municipality, etc., see Table 1). The mutual effects on system functionality are thus very close and are exerted through MDS maintenance (done by the administrator), i.e. different extent of DSD maintenance. The accord of both these approaches is apparent at the level of a drainage outlet - its condition, or defects, indicate the functionality of the mutual relationships between the administrators of both parts of the divided drainage system.

\section{Ad E (state support and subsidies)}

In the two last decades, consultations regarding land drainage or irrigation systems and state support of drainage system repairs and maintenance have practically been abolished. The subsidies for drainage repairs and maintenance were targeted at the owners of drainage systems as well as the farmers. However, the awareness and concern, especially of land owners, was regrettably low. On the other hand, the repairs were not done with adequate professional (and financial) support, and therefore were neither effective nor durable. The complexity of natural conditions of CR along with the topological complexity of constructed drainage systems, as well as the overlay of older systems by the new ones, emphasizes the need for adequate detailed data - primarily expressed in the project documentation. The currently available details in the related information system of public administration section does not reflect this need. Hard copies (paper) of the former AWMA archives are not complete anymore and the systematic digitization of these archives has not even been started. For the entire territory of $\mathrm{CR}$, the land drainage extent is only described by digitized maps of the former AWMA, made at 1:10,000 scale and containing a multitude of errors.

The state funding policy terminated the particular support for production-aimed drainage systems by the operational program "Rural development and multifunctional agriculture in the period 2004-06," because the program was assessed as not interesting enough due to the lack of applications. The possible alternative for 2007-13 could have been the Program of Rural Development, in the part designed for the s.c. "Common Structures Plan" included in the topic Land Consolidations. The funding for this program also met with a lack of interest both from land owners and from land users.

In the program called by the Czech Ministry of Environment, the funding for drainage repairs or rather for adoption of elimination measures may be claimed for "improving the nature and landscape conditions" with the objective to return the runoff regime to the state prior land drainage construction. This program is targeted to enhance water retention in the landscape and to minimize the risks of drought occurrence (but not to stabilize agricultural production), and also to improve the quality of groundwater and surface water as well as soil.

\section{Ad F (the role of the owners' association)}

The law which would define in more detail the rights and duties of water cooperatives as legal entities, being created by co-investment of the land parcel owners, has not yet been approved in the CR. The activities of similar associations abroad as well as in CR in the past have been reported as highly useful [12-14]. Previous bills linked creation of these cooperatives with repair and maintenance duties for irrigation and drainage structures. Historically, these bills have been based on the combination of original local experience and international expertise. Despite the abolishment of water cooperatives (after WWII), they exceptionally still existed in CR even in the 1970s (e.g. close to Jaroměr district in eastern CR). However, their activities were limited by the deformed (socialist) landowner relationships. The newly established water cooperatives would arise on an adequate and currently valid proprietary-legal basis. Water cooperatives could be constituted either as an association or any type of a cooperative or a corporate. Their anticipated goal and responsibility would lie in reconciling the demands of land owners, farmers, and/or state on land and drainage management. Within the given drainage handling and operating rules, approved by a regional Water Management Authority Office, the cooperatives would be able, besides conducting required management and repairs, to e.g. adjust water levels in ditches or water table depths, in accordance with the actual weather conditions and tillage needs.

\section{Ad $G$ (reassessment of agricultural drainage functions in the landscape)}

In view of the areal proportion of drained agricultural land in the CR, corresponding to natural and agricultural conditions (ca 1.06 mil. ha, i.e. ca $1 / 4$ of agricultural land), we cannot expect a significant need for construction of new drainage systems. Construction of a new system will probably rather be considered in a locality with already existing drainage, mainly for economic reasons (the higher cost of old system reconstruction or renovation). In prevailing cases the functioning of the existing systems will be adapted if their technical condition is adequate. This can be deduced from the current behaviour of some land users who are aware of the redundancy of all-season (free) drainage 
and look for technical solutions allowing the control of the excess drainage runoff, namely in consideration of the risk of increasing water deficit in the summer period. Some of these measures are mentioned in Table 4. The runoff controlling mechanisms consist in many types of adjustable, flow-retarding structures placed either in the drainage outlet or in the drainage shafts (manholes) or even on the drains themselves (for DSD). For MDS, devices enabling the manipulation with water level on weirs/sluices in drainage ditches/tubes are to be taken into consideration. These types of measures are similar to the ones applied on controlled drainage systems, e.g. in certain parts of the USA "Corn Belt" States, or in Canada, Sweden, or Italy [20, 24, 53, 54]. Further, non-productive (i.e. environmental) roles of agricultural land are of fundamental importance in limiting or eliminating the functions of land drainage [79].

\section{Discussion of the Effectiveness and Adequacy of Measures on Land Drainage}

Overall, it may be stated that taking into account the proportion of the drained areas in the CR, the number of apparent defects is not very large. However, the need for adaptation options and measures on land drainage is induced on one hand by the current status of drainage systems (failures on drainage or by a change of land management or use), and on the other hand by a motivation given by state subsidies aimed at the extensive management of drained land or primarily at the conservation of environmentally precious areas, as described in $[31,32]$. The potential of the elimination measures on land drainage is derived from the proposed parameters of the realized (built) drainage system.

Based on results acquired within this study, the following hypotheses are considered as valid:

- The regulation/elimination measure will have a lower impact on drainage functioning in comparison with its original (i.e. draining) magnitude. This is partly achieved by preservation of the hydraulic effectiveness of the draining groove compared to the surrounding native soil profile (soil permeability, terrain sloping, path topology) along with sections of the preserved draining pipes.

- The regulation/elimination measures affect water regime both directly in the area of interest but also, according to their placement on drainage, in the topology of the entire drainage system.

The elimination effect of a measure on drainage may be quantified by physically based models or by special soilhydraulic computing tools. In the case of less extensive elimination measures (drainage group or very small subcatchment to tens of ha). However, qualified assessment of the elimination drainage effects will be sufficient based on the evaluation of measurements applied to the particular drainage system or description of the drainage runoff regime.

Regulation of a drainage base level (i.e. water table) in the drainage process plays a crucial role for the water regime of a land parcel. The regulation extent is derived from the height of water level augmentation by a regulating element and from longitudinal drainage slope and drainage lodgement depth. A theoretical lowering of the drain lodgement depth by a regulation will reduce the depth of the soilsaturated layer, which governs the process of groundwater flow toward the drains.

While preserving the same design parameters of the drainage system and the same drainage hydraulic effect, this lowered depth of soil saturated layer will unequivocally lead to a reduction of the drainage runoff as proved experimentally or on models $[21,40,58,73]$. On the other hand, the drainage system will keep all water management functions and criteria for which it has been designed. To quantify the effect of regulation measures on drainage elements, we designed and tested a calculator for a mathematical-physical description of groundwater flow toward drains in the conditions of stable, unstable, and transient drainage flow [80]. This tool is being tested in different soil and drainage conditions and the results are not yet included in this study.

\section{Conclusions}

Our paper brings the first comprehensive study of the state and conditions of agricultural drainage systems in 39 model localities in the $\mathrm{CR}$ as examples of the situation in the former Eastern European Bloc countries, as previously described for Lithuania [4] or East Germany [5]. We present the needs, requirements, and potential management of these systems - in the context of owner-user relationships and expected climatic changes - aimed at increasing water retention time in catchments, its utilization by crops, and improvement in quality. The approach presented in this paper thus attempts to meet the requirements of both national and European directives for water protection related to its quantity and overall landscape ecological condition, of flood protection, as well as of drought-related problems, including the landscape use.

The knowledge gained in this study and the results from abroad show that the former views on promoting intensive agricultural management must be changed, and the issue of protective catchment management together with the role of agricultural drainage must be reassessed [81-83]. This work shows the necessity of the best possible water management in agricultural landscape from the view of the economy, quality of water-related environment, and preservation of crop yields. We also have stressed the possible ways to improve conditions of watercourses, and to increase retention capacity of headwaters or biologically valuable localities by reassessing the existence of undesired functions of agricultural drainage.

For these purposes we have proposed a set of measures regulating or eliminating runoff from the drainage systems, taking into account experience from abroad and including the natural, agricultural, and proprietary-legal specificities of the CR. We proposed a method for selection of these measures based on the diagnostics of the particular drainage system, taking into account the future use of the associated land parcels. 
The inferior accessibility of project documentation of the established drainage systems significantly complicates their effective management. Several rounds of relocation of project documentation archives done in the past in the CR along with several versions of recording systems strongly hampers the orientation during the search for particular drainage system projects. The majority of farmers already possess the skills in working with other territorial information systems (e.g. LPIS on the web) and would welcome complementary detailed data on the drainage systems. So far, such a system is lacking. Most farmers encounter the increasing occurrence of problems with drainage on their land parcels due to waterlogging. The time and financial requirements for maintenance and repairs are augmented every year. However, to minimize the costs, the vast majority of the subjects ensure the maintenance and repairs of drainage systems by themselves. Adequate funding provided by the Czech Ministry of Agriculture and Czech Ministry of the Environment is missing. Though any subsidies would be helpful both for supporting correct draining and renovation practice as well as for reconstruction of the systems aimed at eliminating excessive drainage runoff, forming water accumulation zones, and enhancing water self-cleaning processes.

Extensive fragmentation of the land ownership in CR associated with the drainage system as a unit and the absence of owners' associations, as e.g. water cooperatives, strongly limits the users' activities during the repairs and reconstructions of land drainage. Due to the separation of property administration after 1991 (MDS and DSD), the functional links between DSD and MDS are not respected during maintenance. This unfortunately increases the occurrence of defects caused by the absence of maintenance of hydrologically related water courses or due to damages of land drainage outlets during cleaning of MDS.

The findings summarized in this paper can serve as a basis for rethinking the role of agricultural drainage systems in a landscape and to encourage policy makers to initiate appropriate remedy moves.

\section{Ackowledgements}

This research was supported by projects No. QI 112A174, QI 111C034, and by project "LAPLANT," No. EHP-CZ02-OV-1-027-2014, provided by EEA Grants. The authors wish to thank Šárka Takáčová for language corrections and Jana Maxová for technical assistance.

\section{References}

1. VÁCLAVÍK F. On soil grooving or the art of pipe field drain positioning; E. Grégr book printing: Prague, 92, 1863 [In Czech].

2. KULHAVÝ Z., DOLEŽAL F., FUČÍK P., KULHAVÝ F., KVÍTEK T., MUZIKÁŘ R., SOUKUP M., ŠVIHLA V. Management of agricultural drainage systems in the Czech Republic. Irrigation and Drainage 56, 2007.
3. HIRT U., HAMMANN T., MEYER B. C. Mesoscalic estimation of nitrogen discharge via drainage systems. Limnologica 35, 206, 2005. doi:10.1016/j.limno.2005.06.005

4. MAZILIAUSKAS A. Land use and water management challenges in Lithuanian rural areas. Irrigation and Drainage 53, 315, 2004. doi: 10.1002/ird.110.

5. SCHLEYER C. Economic and Ecological Transformation Processes in East German Water Management Regimes: The Role of Property Rights and Governance Structures. Environmental Management 34, (2), 281, 2004. doi: 10.1007/s00267-003-3009-3

6. HARTVIGSEN M. Land reform and land fragmentation in Central and Eastern Europe. Land Use Policy 36, 330, 2014. http://dx.doi.org/10.1016/j.landusepol.2013.08.016.

7. AGRICULTURAL WATER MANAGEMENT AUTHORITY (AWMA). Annual report from year 2007 on state and management of land drainage and small water courses in the CR. p. 61, 2008 [In Czech].

8. Law No. 92/1991, On the terms for transfer of state property to other persons. [In Czech].

9. Law No. 229/1991, On the adjustment of ownership rights regarding land and other agricultural property. [In Czech].

10. Regulation of Czech Ministry of Agriculture No. 7/2003. On the legal water registry. [In Czech].

11. Law No. 139/2002. On land adjustments and state land offices. [In Czech].

12. BLACKSTOCK K. L., INGRAM J., BURTON R., BROWN K. M., SLEE B. Understanding and influencing behaviour change by farmers to improve water quality. Sci. Total Environ. 408, 5631, 2010. doi:10.1016/j.scitotenv. 2009.04.029

13. GARIN P., BARRAQUÉ B. Why are there so few cooperative agreements between farmers and water services in France? Water policies and the problem of land use rights. Irrigation and Drainage 61, (1), 95, 2012. doi: 10.1002/ird. 1657

14. SCHULTZ B., ZIMMER D., VLOTMAN W. Drainage under increasing and changing requirements. Irrig. and Drain. 56, 3, 2007. doi: $10.1002 /$ ird. 372

15. BRÁZDIL R., CHROMÁ K., DOBROVOLNÝ P., TOLASZ R. Climate fluctuations in the Czech Republic during the period 1961-2005. J. Climatol. 29, (2), 223, 2008.

16. DANKERS R. FEYEN L., CHRISTENSEN O.B., DE ROO A. Future changes in flood hazard in Europe. In: Proceedings of the Third international conference on climate and water. Finnish Environment Institute: Helsinki, pp. 115120, 2007.

17. FELDMAN D. Adaptation as a Water Resource Policy Challenge - Institutions and Science. Journal of Water Resource and Protection 5, (4A), 1, 2013. doi: 10.4236/jwarp.2013.54A001

18. KOVÁŘ P., VRÁNA I., VAŠŠOVÁ D. Stakeholder Group Consensus based on Multi-Aspect Hydrology Decision Making. Journal of Hydrology and Hydromechanics 60, (4), 252, 2012. doi: 10.2478/v10098-012 -0022-3.

19. DE WRACHIEN D., FEDDES R. Global warming and drainage development: Perspective and challenges. Irrigation and Drainage 53, 215, 2004. doi: 10.1002/ird.118

20. MADRAMOOTOO C. A., JOHNSTON W. R., AYARS J. E., EVANS R. O., FAUSEY N. R. Agricultural drainage management, quality and disposal issues in North America. Irrigation and Drainage 56, 5, 2007. doi: 10.1002/ird.343

21. SKAGgS R. W., BREVE M. A., GILliAM J. W. Hydrologic and water quality impacts of agricultural drainage. Crit. Rev. Env. Sci. Tec. 24, (1), 1, 1994. 
22. KRÖGER R., COOPER C. M., MOORE M. T. A preliminary study of an alternative controlled drainage strategy in surface drainage ditches: Low-grade weirs. Agr. Water Manage. 95, 678, 2008. doi:10.1016/j.agwat.2008.01.006

23. RADČENKO I. Hydrodynamic problems of subsurface irrigation by control drainage - Transaction of Ninth Congress of ICID: Moscow, R40, Q31, pp. 717-733, 1975.

24. TAN C. S., ZHANG T. Q. Surface runoff and sub-surface drainage phosphorus losses under regular free drainage and controlled drainage with sub-irrigation systems in southern Ontario. Can. J. Soil Sci. 91, 349, 2011. doi:10.4141/ CJSS09086

25. KOPECKÝ J. Some experiences in the field of soil drainage. Abstract from the $8^{\text {th }}$ Agricultural Congress in Vienna: Vienna, 18, 1922 [In Czech].

26. JŮVA K. Drainage of soil; SZN: Prague, 526, 1957 [In Czech].

27. Direction - Controlled Agricultural Drainage Systems; MZVz CSR and MPVz SSR, VUZZP: Prague, 1985 [In Czech].

28. KULHAVÝ F. Optimization of soil water regime in areas with land drainage. In: Land drainage and regulation of soil water regime. Harvest: Minsk, pp 183-200, 1981 [In Russian].

29. KULHAVÝ F. Complex Solution of Hydromelioration Structures. In Trans. Twelfth Congr. International Commission on Irrigation and Drainage, Q38, R14, pp. 255-264, 1983.

30. KULHAVÝ F. Control Drainage Systems. In Stavební ročenka; SNTL: Praha, pp. 212-267, 1992 [In Czech].

31. BLANN K. L., ANDERSON J. L., SANDS G. R., VONDRACEK B. Effects of Agricultural Drainage on Aquatic Ecosystems: A Review. Crit. Rev. Env. Sci. Tec. 39, (11), 909, 2009. doi: 10.1080/10643380801977966

32. SPALING H., SMIT B. A conceptual model of cumulative environmental effects of agricultural land drainage. Agriculture, Ecosystems and Environment 53, 99, 1995.

33. HELMERS M., CHRISTIANSON R., BRENNEMAN G., LOCKETT D., PEDERSON C. Water table, drainage, and yield response to drainage water management in southeast Iowa. J. Soil Water Conserv. 67, (6), 495, 2012. doi: 10.2489/jswc.67.6.495

34. POOLE C. A., SKAGgS R. W., CHESCHIER G. M., YOUSSEF M. A., CROZIER C. R. Effects of drainage water management on crop yields in North Carolina. J. Soil Water Conserv. 68, (6), 429, 2013. doi:10.2489/jswc.68.6.429

35. AHIABLAME L. M., CHAUBEY I., SMITH D. R., ENGEL B. A. Effect of tile effluent on nutrient concentration and retention efficiency in agricultural drainage ditches. Agr. Water Manage. 98, 1271, 2011. doi:10.1016/j.agwat. 2011.03.002

36. BROWN C. D., VAN BEINUM W. Pesticide transport via sub-surface drains in Europe. Environ. Pollut. 157, 3314, 2009. doi:10.1016/j.envpol.2009.06.029

37. FUČÍK P., HEJDUK T., PETERKOVÁ J. Quantifying Water Pollution Sources in a Small Tile-drained Agricultural Watershed. Clean Soil Air Water, 2014. doi: 10.1002/clen.201300929

38. KING K. W., WILLIAMS M. R., MACRAE M. L., FAUSEY N. R., FRANKENBERGER J., SMITH D. R., KLEINMAN P. J. A., BROWN L. C. Phosphorus Transport in Agricultural Subsurface Drainage: A Review. J. Environ. Qual. 44, 467, 2015. doi:10.2134/jeq2014.04.0163

39. KRÖGER R., PIERCE S. C., LITTLEJOHN K. A., MOORE M. T., FARRIS J. L. Decreasing nitrate-N loads to coastal ecosystems with innovative drainage management strategies in agricultural landscapes: An experimental approach. Agr. Water Manage. 103, 162, 2012. doi:10.1016/j.agwat.2011.11.009

40. MORRISON J., MADRAMOOTOO C. A., CHIKHAOUI M. Modeling the influence of tile drainage flow and tile spacing on phosphorus losses from two agricultural fields in southern Québec. Water Quality Research Journal of Canada 48, (3), 279, 2013. doi:10.2166/wqrjc. 2013.053

41. TIEMEYER B., FRINGS J., KAHLE P., KÖHNE S., LENNARTZ B. A comprehensive study of nutrient losses, soil properties and groundwater concentrations in a degraded peatland used as an intensive meadow - Implications for re-wetting. Journal of Hydrology 345, (1-2), 2007. doi: 10.1016/j.jhydrol.2007.08.002

42. WILSON L. WILSON J., HOLDEN J., JOHNSTONE I., ARMSTRONG A., MORRIS M. Ditch blocking, water chemistry and organic carbon flux: Evidence that blanket bog restoration reduces erosion and fluvial carbon loss. Sci. Total Environ. 409, 2010, 2011. doi:10.1016/j.scitotenv. 2011.02.036

43. FUČÍK P., NOVÁK P., ŽÍŽALA D. A combined statistical approach for evaluation of the effects of land use, agricultural and urban activities on stream water chemistry in small tile-drained catchments of south Bohemia, Czech Republic. Environmental Earth Sciences, 2014. Doi. 10.1007/s12665014-3131-y

44. HEILMAN P. MALONE R.W., MA L., HATFIELD J.L., AHUJA L.R., BOYLE K.P., KANWAR R.S. Extending results from agricultural fields with intensively monitored data to surrounding areas for water quality management. Agricultural Systems 106, (59-71), 2012. doi:10.1016/j. agsy.2011.10.010

45. KENNEDY C. D. BATAILLE C., LIU Z., ALE S., VAN DE VELDE J., ROSWELL C. R., BOWLING L. C., BOWEN G. J. Dynamics of nitrate and chloride during storm events in agricultural catchments with different subsurface drainage intensity (Indiana, USA). J. Hydrol. 466-467 (1-10), 2012. http://dx.doi.org/10.1016/j.jhydrol.2012.05.002

46. REID D. K., BALL B., ZHANG T. Q. Accounting for the risks of phosphorus losses through tile drains in a phosphorus index. J. Environ. Qual. 41, 1720, 2012. doi:10.2134/ jeq2012.0238

47. ANDERSSON H., BERGSTRÖM L., DJODJIC F., ULÉN B., KIRCHMANN H. Topsoil and Subsoil Properties Influence Phosphorus Leaching from Four Agricultural Soils. J. Environ. Qual. 42, 455, 2013. doi: $10.2134 /$ jeq 2012.0224

48. VIDON P., HUBBARD H., CUADRA P., HENNESSY M. Storm phosphorus concentrations and fluxes in artificially drained landscapes of the US Midwest. Agricultural Sciences 3, (4), 474, 2012. http://dx.doi.org/10.4236/ as. 2012.34056

49. THOMAS D. L., PERRY C. D., EVANS R. O., IZUNO F. T., STONE K. C., GILLIAM J. W. Agricultural drainage effects on water quality in Southeastern U.S. Journal of Irrigation and Drainage Engineering 121, (4), 277, 1995.

50. Water Framework Directive. Directive 2000/60/EC of the European Parliament and of the Council of 23 October 2000 establishing a framework for Community action in the field of water policy.

51. Groundwater Directive. Directive 2006/118/EC of the European Parliament and of the Council of 12 December 2006 on the protection of groundwater against pollution and deterioration.

52. Flood Directive. Directive 2007/60/EC on the assessment and management of flood risks. 
53. BONAITI G., BORIN M. Efficiency of controlled drainage and subirrigation in reducing nitrogen losses from agricultural fields. Agr. Water Manage. 98, 343, 2010. doi:10.1016/j.agwat.2010.09.008

54. WESSTRÖM I. JOEL A., MESSING I. Controlled drainage and subirrigation - A water management option to reduce nonpoint source pollution from agricultural land. Agric. Ecosyst. Environ, 2014. http://dx.doi.org/10.1016/j.agee.2014.03.017

55. BRASKERUD B. C., TONDERSKI K. S, WEDDING B., BAKKE R., BLANKENBERG A.-G. B., ULÉN B., KOSKIAHO, J. Can Constructed Wetlands Reduce the Diffuse Phosphorus Loads to Eutrophic Water in Cold Temperate Regions? J. Environ. Qual. 34, 2145, 2005. doi:10.2134/jeq2004.0466

56. HERNANDEZ-RAMIREZ G., BROUDER S. M., RUARK M. D., TURCO R. F. Nitrate, Phosphate, and Ammonium Loads at Subsurface Drains: Agroecosystems and Nitrogen Management. J. Environ. Qual. 40, 1229, 2011. doi:10.2134/jeq2010.0195

57. MASARIK K. C., NORMAN J. M., BRYE K. R. LongTerm Drainage and Nitrate Leaching below Well-Drained Continuous Corn Agroecosystems and a Prairie. Journal of Environmental Protection 5, 240, 2014. http://dx.doi.org/10.4236/jep.2014.54028

58. SINGER J. W., MALONE R. W., JAYNES D. B., MA L. Cover crop effects on nitrogen load in tile drainage from Walnut Creek Iowa using root zone water quality (RZWQ) model. Agr. Water Manage. 98, 1622, 2011. doi:10.1016/j.agwat.2011.05.015

59. SCHILLING K. E., MCLELLAN E., BETTIS E. A. Letting Wet Spots be Wet: Restoring Natural Bioreactors in the Dissected Glacial Landscape. Environmental Management 52, 1440, 2013. doi: 10.1007/s00267-013-0142-5

60. TANNER C. C., SUKIAS J. P. S. Multiyear Nutrient Removal Performance of Three Constructed Wetlands Intercepting Tile Drain Flows from Grazed Pastures. J. Environ. Qual. 40, 620, 2011. doi: $10.2134 /$ jeq2009.0470

61. TOURNEBIZE J., GRAMAGLIA C., BIRMANT F., BOUAFRA S., CHAUMONT C., VINCENT B. Co-design of constructed wetlands to mitigate pesticide pollution in a drained catch-basin: A solution to improve groundwater quality. Irrigation and Drainage 61, (1), 75, 2012. doi: 10.1002/ird. 1655

62. WOLI K. P., DAVID M. B., COOKE R. A., MCISAAC G. F., MITCHELL C. A. Nitrogen balance in and export from agricultural fields associated with controlled drainage systems and denitrifying bioreactors. Ecological Engineering 36, (11), 1558, 2010. doi:10.1016/j.ecoleng.2010.04.024

63. DAMPNEY P., MASON, P. GOODLASS G., HILLMAN J. Methods and measures to minimise the diffuse pollution of water from agriculture - a critical appraisal. Final Report of DEFRA Project NT2507, 130, 2002

64. USDA - NRCS. Water Management (Drainage). Chapter 14. Part 650 Engineering Field Handbook. National Engineering Handbook. pp. 202, 2001.

65. MADRAMOOTOO C. A., JOHNSTON W. R., WILLARDSON L. S. (Eds.). Management of agricultural drainage water quality. ICID, FAO, Water Reports 13: Rome, M-56, 1997. Available online at:

http://www.fao.org/docrep/W7224E/w7224e00.htm\#Contents accessed 1.4.2014.

66. BRITO M. G., COSTA C. N., ALMEIDA J. A., VENDAS D., VERDIAL P. H. Characterization of maximum infiltration areas using GIS tools. Engineering Geology 85, (1-2), 14, 2006. doi: 10.1016/j.enggeo.2005.09.022
67. MARSHALL M. R. BALLARD C. E., FROGBROOK Z L., SOLLOWAY I., MCINTYRE N., REYNOLDS B., WHEATER H. S. The impact of rural land management changes on soil hydraulic properties and runoff processes: results from experimental plots in upland UK. Hydrol. Process. 28, (4), $2617,2014$.

68. DOLEŽAL F., KVÍTEK T. The Role of Recharge Zones, Discharge Zones, Springs and Tile Drainage Systems in Peneplains of Central European Highlands with Regard to Water Quality Generation Processes. Phys. Chem. Earth 29, Parts A/B/C, 775, 2004.

69. HOLKO L. Hydrological research in experimental and representative catchments in Czech republic and Slovak republic. J. Hydrol. Hydromech 54, (2), 2006.

70. Regulation of Czech Ministry of Agriculture No. 225/2001 On the detailed delimitation of ameliorative constructions on agricultural land and the scope of compulsory maintenance and repairs. [In Czech].

71. TLAPÁKOVÁ L., KULHAVÝ Z. Application of remote sensing methods for delineation of subsurface drainage systems in the Czech Republic. Vodní hospodářství 6, 229, 2009 [In Czech]

72. TLAPÁKOVÁ L., ŽALOUDÍK J., PELÍŠEK I., KULHAVÝ Z. Identification of agricultural drainage systems by remote sensing methods - a thematic introduction. Vodní hospodářství 2, 18, 2014.

73. TETZLAFF B., KUHR P., VEREECKEN H., WENDLAND F. Aerial photograph-based delineation of artificially drained areas as a basis for water balance and phosphorus modelling in large river basins. Physics and Chemistry of the Earth 34, (8-9), 552, 2009. doi: 10.1016/j.pce.2009.02.002

74. VOPRAVIL J., CHLUBNA L., VLČEK V., KULHAVÝ Z., KULÍŘOVÁ P. Proposal of identification system for agricultural drainage in the Czech Republic. Proceedings of the conference "Voda, půda a rostliny": Křtiny, 2013 [In Czech].

75. RISWC Identification system for land drainage in the Czech Republic. 2013 [In Czech].

Mapservers http://meliorace.vumop.cz and http://geoportal. vumop.cz/index.php?projekt=meliorace

76. HARTVIGSEN M. Land reform and land fragmentation in Central and Eastern Europe. Land Use Policy 36, 330, 2014. http://dx.doi.org/10.1016/j.landusepol.2013.08.016

77. SKLENICKA P., JANOVSKA V., SALEK M., VLASAK J., MOLNAROVA K. The Farmland Rental Paradox: Extreme land ownership fragmentation as a new form of land degradation. Land Use Policy 38, 587, 2014. doi:10.1016/j.landusepol.2014.01.006

78. TLAPÁKOVÁ L., KARÁSEK P., STEJSKALOVÁ D. Retrospective Evaluation of the Extent and Spatial Changes of Realized Hydromelioration Systems. Pol. J. Environ. Stud. 22, (6), 1855, 2013.

79. KULHAVÝ Z., FUČÍK P., TLAPÁKOVÁ, L. Operating procedures for elimination of the harmful effects of agricultural drainage systems in a landscape; Ministry of Environment of CR, RISWC v.v.i.: Prague, pp 28+79, 2013 [In Czech]. http://www.mzp.cz/cz/prirode_blizka_opatreni

80. KULHAVÝ Z., ŠTIBINGER J. Calculator for quantification of the regulation effect of drainage runoff. 2014 [In Czech]. http://www.hydromeliorace.cz/sw/regulace/

81. HERING D., BORJA A. CARSTENSEN J., CARVALHO L., ELLIOTT M., FELD C.K. The European Water Framework Directive at the age of 10: A critical review of the achievements with recommendations for the future. Sci. Total Environ. 408, 4007, 2010. doi:10.1016/j.scitotenv. 2010.05.031 
82. LEMKE A. M., KIRKHAM K. G., LINDENBAUM T. T., HERBERT M. E., TEAR T. H., PERRY W. L., HERKERT J. R. Evaluating agricultural best management practices in tiledrained subwatersheds of the Mackinaw River, Illinois. J. Environ. Qual. 40, (4), 1215, 2011. doi: 10.2134/jeq2010.0119
83. RAHMAN M. M., LIN Z., JIA X., STEELE D. D., DESUTTER T. Impact of subsurface drainage on streamflows in the Red River of the North basin. J. Hydrol. 511, 474, 2014. http://dx.doi.org/10.1016/j.jhydrol.2014. 01.070 